\title{
Process optimisation for the production of papaya leaf extract based therapeutic whey beverage
}

\author{
Singh, H.K., $\otimes^{1}$ Puranik, D.B. ${ }^{2}$, Poornima ${ }^{1}$, Sain, M. ${ }^{1}$
}

Received: 08.04.2021

Revised: 14.05 .2021

Accepted: 25.05.2021

\begin{abstract}
The therapeutic benefit of whey with papaya leaf extract was tried to exploit. In the present study, a therapeutic whey beverage was developed using the Extract from Papaya leaves. Various levels of papaya leaf extract were tried at 15, 20, and 25 per cent, sucrose at 7,10 and 15 per cent and Stevia at 1, 1.5 and 2 per cent. Based on the sensory scores of sensory evaluations by expert panellists, amongst all, 20 per cent papaya leaf extract, 15 per cent sucrose, and Stevia up to 1.5 per cent were ideal for preparing this therapeutic beverage. Finally, based on sensory scores, this therapeutic whey beverage with the addition of papaya leaf extract was optimised as a drink and was used for further detailed analysis.
\end{abstract}

Key words: Papaya Leaf Extract, Stevia, Therapeutic beverage, Whey beverage.

\section{Introduction}

Interest in whey processing and antipollution regulations, use of Whey in the food system has been under active consideration by the dairy processor in recent times. About 40 per cent out of the global production of Whey is still disposed of as raw Whey \& nearly 6,50,000 tonnes of paneer are produced per year in India, which yields 3.3 million tonnes of Whey per annum (Rajarajan et al., 2016). Whey contains total milk solids (45-50\%), milk sugar $(\sim 70 \%)$, milk proteins $(\sim 20 \%)$, and minerals (70-90\%) of the milk from which it is formed, along with retention of nearly all the water-soluble vitamin B complexes such as riboflavin, thiamine, folic acid, pantothenic acid and vitamin $\mathrm{C}$ (ascorbic acid) in milk that were present originally. The addition of some simple ingredients to the Whey like sucrose, colour and flavour can improve the nutritive value, taste and acceptability. Several attempts have been made to utilise Whey in manufacturing of various food formulae or products like in cheese, infant milk foods, protein-rich powders for the athletic population, along with increased scopes to utilise the Whey in making flavoured milk or fruit beverages for beverage manufacturing industries (Gupta et al., 2013). In

Author's Address
${ }^{1}$ Dairy Engineering Division, ICAR-National Dairy Research
Institute, Karnal, Haryana, India- 132001
${ }^{2}$ Department of Dairy Technology, Dairy Science College,
Bengaluru, Karnataka, India -560024
E-mail.: himanshukumarsingh867@gmail.com

the era of the fast-growing population, changing lifestyle, consumers are now looking for products that provide value addition and meet health requirements beyond nutrition which can also be used as a value addition to food product of specific health benefits like reducing the risk of developing diseases, overall well-being along with ample of health benefits. The recent trend in developed countries is the use of low calorie/low-fat products and herbs in therapeutic beverage because of health consciousness. The Papaya (Carica Papaya) plant has ample medicinal properties such as uterotonic, nephroprotective, anti-inflammatory, anti-tumour, etc. Many cohort studies have shown that the leaves of Papaya contain ample active components that can improve the overall antioxidant potential in the blood along with reduced lipid peroxidation levels; for example, it contains components like papain, chymopapain, tocopherol, flavonoids, cystatin, ascorbic acid, glucosinolates and cyanogenic glucosides (Roshan et al., 2014). In addition to this, the Papaya plant also produces natural compounds like annonaceous acetogenins in its Leaf bark along with twig tissues that have highly anti-tumour \& pesticide properties. The presence of a greater number of natural self-defence factors in the tree gives the plant the resistance power against infestation of insect and diseases. Papaya leaf extract, or the tea made of it, has an immense reputation as a "tumour destroying agent" 
(Baskaran et al., 2012). Furthermore, studies have shown to increase platelets count, antimicrobial activity, hypoglycaemic effect etc.

Stevia (Stevia rebaudiana bertoni) is a low or zerocalorie natural sweetener that is locally called a "sweet herb or honey Leaf" and is used by herbalists as a sweetener. The leaves of the stevia plant contain sweetening factors like stevioside, diterpene glycosides, rebaudioside (A-F), dulcoside $\&$ steviolbioside, and the presence of these compounds give Stevia its sweet taste and has shown a commercial status as low calorie / zero calorie sugar substitute in different foods products, health beverages along with medicinal use all over the world (Savita et al., 2004 and Gupta et al., 2013). The researchers have identified Stevia for its health benefits, such as anti-bacterial, antioxidant, anti-hyperglycemic (insulinotropic properties), antihyperlipidemic, etc. The addition of Stevia to beverage is beneficial in terms of its low-calorie content along with health benefits (Hazali et al., 2014).

Consumption of Whey beverages is gaining popularity in India, and Whey has excellent nutritional value due to the presence of health benefiting protein source. Hence, Whey can be used in beverage manufacturing which enhances the consumer's nutrition intake which will provide therapeutic reimbursements and inclusion of herbs such as Papaya Leaf Extract further enhances its therapeutic value, and the addition of low-calorie natural sweetener stevia helps in cutting of white sugar (Punnagaiarasi et al., 2017). Keeping this in view, an attempt has been made in this investigation to develop a papaya leaf extract based therapeutic Whey beverage.

\section{Materials and Methods}

Ingredients Paneer whey was obtained during the preparation of paneer in dairy technology laboratory, dairy science college, Hebbal, Bengaluru, sucrose was obtained from the local market, Stevia was procured from Jhanil health care Pvt. Ltd., Punjab and papaya leaf extract were obtained from campus grown plants.

Preparation of Paneer Whey was obtained during the preparation of paneer in dairy technology laboratory, dairy science college, Hebbal,
Bengaluru, using standard method followed by Divya et al. (2014).

Preparation of Papaya Leaf Extract Fresh organic papaya leaves were obtained from campus grown plants. The Extract was prepared by washing, slicing, dipped in the salt solution, blanching $\left(90^{\circ} \mathrm{C} / 5 \mathrm{~min}\right)$ of fresh leaves, and papaya leaf extract was manually prepared by using a mixer grinder with the addition of 1:2 ratio of water and filtered by using sterilised muslin cloth followed by heat treatment of extract at $80{ }^{\circ} \mathrm{C} / 5$ min.

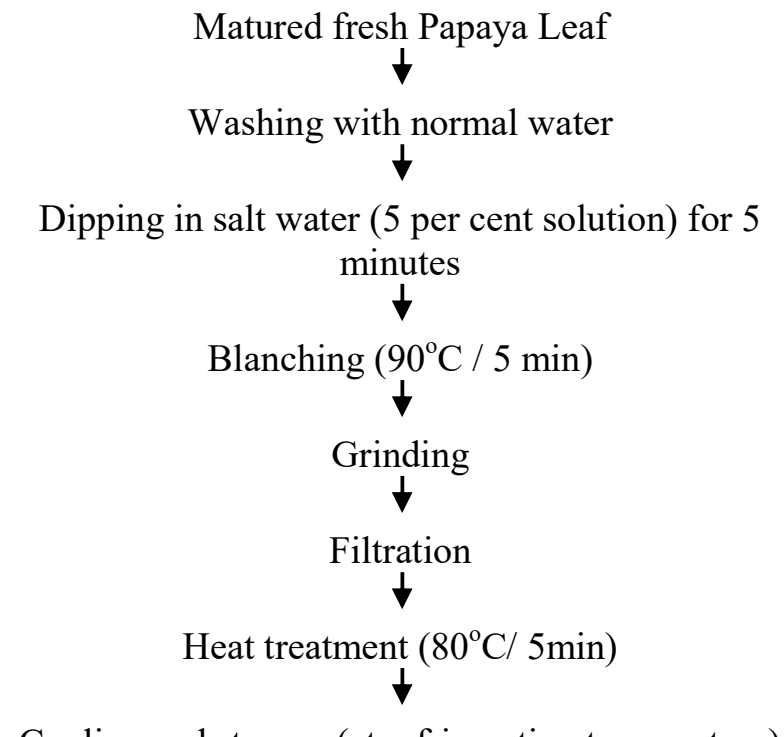

Cooling and storage (at refrigeration temperature)

\section{Figure 1: Preparation of papaya leaf extract}

Preparation of therapeutic Whey beverage Fresh papaya leaf extract was added by blending it with freshly prepared whey at a different ratio, respectively, with the incorporation of 5 per cent sucrose followed by heat treatment at $80{ }^{\circ} \mathrm{C} / 5 \mathrm{~min}$ and then cooled. The resultant blends were subjected for sensory evaluation studies to adjudge by a panel of judges at chilled condition. After optimisation of papaya leaf extract in Whey, sucrose and Stevia, optimisation was carried out at different levels in previously treated Whey and subjected to sensory and statistical evaluation. The optimised therapeutic whey beverage was stored for further analysis.

Sensory evaluation The resultant blends were subjected to sensory evaluation for the attributes, 
i.e., colour and appearance, consistency, flavour \& overall acceptability, with the help of a 9-point hedonic scale in chilled condition by a panel of experts, the optimised blend was used in further studies. The scores obtained were statistically evaluated.

Fresh filtered Paneer Whey
$\downarrow$
Blending treated Papaya Leaf Extract (15,20 \& $25 \%$ )
$\downarrow$
Addition of sucrose (7, $10 \& 15 \%)$, Stevia $(1.0,1.5 \&$
$2.0 \%)$
$\downarrow$
Blending/Mixing
$\downarrow$
Filling into the glass bottle
$\downarrow$
Heat Treatment ( $80^{\circ} \mathrm{C} / 5$ min)
$\downarrow$
Cooling (room temperature)
$\downarrow$
Storage $\left(7 \pm 1^{\circ} \mathrm{C}\right)$

Fig 2: Flowchart for preparation of papaya leaf extract based low-calorie whey beverage

Sensory evaluation The resultant blends were subjected to sensory evaluation for the attributes, i.e., colour and appearance, consistency, flavour \& overall acceptability, with the help of a 9-point hedonic scale in chilled condition by a panel of experts, the optimised blend was used in further studies. The scores obtained were statistically evaluated.

Statistical analysis The design of the experiment was statistically evaluated. Results obtained were the average of a minimum of three replications which was statistically analysed by subjecting to statistical analysis tool (R Programme, R-Version, Ri386 3.4.3) for precise interpretation that helped in further discussion (Zar, 2003).

\section{Results and Discussion \\ Effect of blending of papaya leaf extract and whey on the sensory characteristics of therapeutic Whey beverage}

The whey and papaya leaf extract were mixed in the ratio $85: 15,80: 20$ and 75:25 per cent, which has given a sensory score for colour and appearance of 7.66, 8.16 and 7.33, respectively. A similar trend of scores was observed for consistency $(7.16,7.66$ and $6.83)$, respectively, and scores for flavour were $6.16,6.83 \& 5.66$, respectively, whereas the overall acceptability scores were 6.33, 7.16 and 5.83, respectively (Table 1). It was evident from the sensory scores that blending 20 per cent of papaya leaf extract with paneer whey was optimum as adjudged by selected expert panellists. Also, it is evident from the results that the control sample was rated lower with regard to sensory attributes as compared to other experimental whey beverage samples prepared by blending papaya leaf extract at different levels $(15,20$ and 25 per cent). These results obtained were in support with observations provided by Prashanth et al. (2018) and Punnagaiarasi et al. (2017). They observed that blending any fruit juice to paneer Whey from 10 to 25 per cent yields an acceptable beverage. In contrast, Chatterjee et al. (2015) reported that blending 40 per cent of orange juice in Whey was also acceptable. Furthermore, Shankarlingayya (2014) experimental reports showed that including 5 per cent of Guduchi extract was acceptable in fruit-based Whey beverage. Hence, 20 per cent of papaya leaf extract addition to whey was optimised and was used for further comprehensive studies.

Effect of different levels of sucrose on the sensory characteristics of papaya leaf extract blended therapeutic whey beverage.

The effect of the addition of different per cent of sucrose $(7,10$ and $15 \%)$ on sensory characteristics of papaya leaf extract based therapeutic whey beverage and control is represented in Table 2. It was observed from the sensory score (Table 2) that adding sucrose at different levels has significant effects on flavour \& overall acceptability of therapeutic whey beverage. The sensory scores for colour and appearance, consistency, flavour and overall acceptability for the control sample were $8.16,7.83,6.16 \& 6.66$, respectively. The sensory scores obtained during sensory evaluation by an expert panel for colour and appearance were 8.16 in sucrose addition, and consistency scores were 7.66 , 7.66 and 7.83, which were non-significant for 7, 10 and 15 per cent of sucrose addition. But it had shown a significant $(P \leq 0.05)$ effect on both flavour and overall acceptability. The scores for flavour were $7.0,7.33$ and 8.30 , respectively, while the score for overall acceptability were 7.16, 7.66 and 
Singh et al.

Table 1: Effect of blending of papaya leaf extract and whey on the sensory characteristics of therapeutic whey beverage

\begin{tabular}{|c|c|c|c|c|}
\hline \multirow{2}{*}{$\begin{array}{l}\text { Whey: Papaya leaf } \\
\text { extract (per cent) }\end{array}$} & $\begin{array}{l}\text { Colour and } \\
\text { appearance }\end{array}$ & Consistency & Flavour & $\begin{array}{c}\text { Overall } \\
\text { acceptability }\end{array}$ \\
\hline & \multicolumn{4}{|c|}{ Scores secured on 9 point hedonic scale } \\
\hline Control (100:0) & $7.66^{\mathrm{a}}$ & $7.66^{\mathrm{a}}$ & $8.16^{\mathrm{a}}$ & $7.83^{\mathrm{a}}$ \\
\hline $85: 15$ & $7.83^{\mathrm{a}}$ & $7.16^{\mathrm{a}}$ & $6.16^{b}$ & $6.33^{\mathrm{b}}$ \\
\hline $80: 20$ & $8.16^{\mathrm{a}}$ & $7.66^{\mathrm{a}}$ & $6.83^{\mathrm{c}}$ & $7.16^{\mathrm{c}}$ \\
\hline $75: 25$ & $7.33^{\mathrm{a}}$ & $6.83^{\mathrm{b}}$ & $5.66^{\mathrm{d}}$ & $5.83^{\mathrm{d}}$ \\
\hline C.D $(P \leq 0.05)$ & 0.95 & 0.80 & 1.32 & 1.24 \\
\hline
\end{tabular}

Note: All values are average of three trials, Values with the same superscripts in a column indicate no significant difference at $P \leq 0.05$, Control: Whey +5 per cent sucrose

Table 2: Effect of different levels of sucrose on the sensory characteristics of papaya leaf extract based therapeutic whey beverage

\begin{tabular}{|c|c|c|c|c|}
\hline \multirow{3}{*}{$\begin{array}{l}\text { Levels of Sucrose } \\
\text { (per cent) }\end{array}$} & \multicolumn{4}{|c|}{ Sensory Attributes } \\
\hline & $\begin{array}{l}\text { Colour and } \\
\text { appearance }\end{array}$ & Consistency & Flavour & $\begin{array}{c}\text { Overall } \\
\text { acceptability }\end{array}$ \\
\hline & \multicolumn{4}{|c|}{ Scores secured on 9 points hedonic scale } \\
\hline Control (5\%) & $8.16^{\mathrm{a}}$ & $7.83^{\mathrm{a}}$ & $6.16^{\mathrm{a}}$ & $6.66^{\mathrm{a}}$ \\
\hline $7 \%$ & $8.16^{\mathrm{a}}$ & $7.66^{\mathrm{a}}$ & $7.0^{\mathrm{a}}$ & $7.16^{\mathrm{a}}$ \\
\hline $10 \%$ & $8.16^{\mathrm{a}}$ & $7.66^{\mathrm{a}}$ & $7.33^{\mathrm{a}}$ & $7.5^{\mathrm{ab}}$ \\
\hline $15 \%$ & $8.16^{\mathrm{a}}$ & $7.83^{\mathrm{a}}$ & $8.30^{b}$ & $8.16^{\mathrm{bc}}$ \\
\hline C.D $(P \leq 0.05)$ & NS & 0.83 & 0.95 & 0.58 \\
\hline
\end{tabular}

Note: All values are average of three trials, NS - Non - Significant, Values with the same superscripts in a column indicate no significant difference at $\boldsymbol{P} \leq \mathbf{0 . 0 5}$, Control: 80 per cent Whey +20 per cent PLE +5 per cent sucrose, Whey: Papaya Leaf Extract (4:1)

Table 3: Effect of different levels of Stevia on the sensory characteristics of Papaya Leaf Extract based therapeutic Whey beverage

\begin{tabular}{|c|c|c|c|c|}
\hline \multirow{3}{*}{$\begin{array}{l}\text { Levels of Stevia } \\
\text { (Per cent) }\end{array}$} & \multicolumn{4}{|c|}{ Sensory attributes } \\
\hline & $\begin{array}{l}\text { Colour and } \\
\text { appearance }\end{array}$ & Consistency & Flavour & $\begin{array}{c}\text { Overall } \\
\text { acceptability }\end{array}$ \\
\hline & \multicolumn{4}{|c|}{ Scores secured on 9 points hedonic scale } \\
\hline Control (5\%) & $8.16^{\mathrm{a}}$ & $7.66^{\mathrm{a}}$ & $7.0^{\mathrm{a}}$ & $7.33^{\mathrm{a}}$ \\
\hline $1 \%$ & $8.16^{\mathrm{a}}$ & $7.66^{\mathrm{a}}$ & $7.0^{\mathrm{a}}$ & $7.5^{\mathrm{a}}$ \\
\hline $1.5 \%$ & $8.16^{\mathrm{a}}$ & $8.0^{\mathrm{a}}$ & $8.16^{b}$ & $8.33^{b}$ \\
\hline $2.0 \%$ & $8.16^{\mathrm{a}}$ & $7.83^{\mathrm{a}}$ & $5.33^{c}$ & $6.16^{\mathrm{c}}$ \\
\hline C.D $(P \leq 0.05)$ & NS & 0.819 & 2.30 & 1.768 \\
\hline
\end{tabular}

Note: All values are average of three trials, NS - Non - Significant, Values with the same superscripts in a column indicate no significant difference at $P \leq 0.05$, Control: 80 per cent Whey +20 per cent $P L E+5$ per cent sucrose, Whey: Papaya Leaf Extract (4:1)

8.16 at 7, 10 and 15 per cent of sucrose blending in Whey beverage, and Shankarlingayya (2014) therapeutic whey beverage. Among all the samples, reported that 8 per cent sucrose level is required to it was understood from the scores of sensory evaluations that adding 15 per cent sucrose was optimum as adjudged by the sensory evaluators. Similar observations were made by Bhavsagar et al. (2010), who showed in their study that 8 per cent of sucrose is required in pineapple-based Whey beverage. Girisha (2011) reported 6 per cent addition of sucrose level in kokum blended paneer reported that 8 per cent sucrose level is required to
mask the bitter flavour of Guduchi which are in support with this study, that 15 per cent sucrose addition resulted in acceptable whey-based beverage, when compared to other treatments, as papaya leaf extract added ( 20 per cent) was very bitter in taste so to overcome the high bitterness, higher amount of sucrose was the required. 
Effect of different levels of Stevia on the sensory characteristics of papaya leaf extract blended therapeutic whey beverage

The effect of adding different levels of Stevia (1, 1.5 and 2 per cent) on sensory characteristics of Papaya Leaf Extract based therapeutic Whey beverage and control is represented in Table 3. It can be observed that the addition of Stevia at different levels has significant effects on flavour \& overall acceptability of therapeutic Whey beverage. The sensory scores for the control sample for colour and appearance, consistency, flavour and overall-acceptability attributes were $8.16,7.66,7.0$ and 7.33 , respectively. The sensory scores for colour and appearance were 8.16 for all the levels of stevia addition, and for consistency, it was 7.66, 8.0 and 7.83 for $1,1.5$ and 2 per cent level of stevia addition, respectively, which was non-significant. But it had a significant effect on both flavour and overall acceptability. The flavour and overall acceptability scores for stevia addition were 7.0, $8.16 \& 5.33$ and $7.50,8.33 \& 6.16$ for $1,1.5$ and 2 per cent, respectively. Among all the samples, it was evident from the scores given by evaluators of sensory evaluation that adding 1.5 per cent stevia was ideal, and this product was used for additional studies. This stevia-based beverage is a low-calorie papaya leaf extract based therapeutic Whey beverage. Similar work was conducted by Ritu et

\section{References}

Baskaran, C., Ratha Bai, V., Velu, S., and Kumaran, K. 2012. The efficacy of carica Papaya Leaf Extract on some bacterial and a fungal strain by well diffusion method. Asian Pacific Journal of Tropical Disease, s658-s662.

Bhavsagar, M. S., Awaz, H. B. and Patange, U. L. 2010. Manufacture of pineapple flavoured beverage from chhana Whey. Journal of Dairying Foods \& Home Sciences, 29(2): $110-113$.

Chatterjee, G., Neve, D. J., Dutta, A. and Das, S. 2015. Formulation and statistical evaluation of a ready-to-drink Whey based orange beverage and its storage stability. Revista mexicana de ingenierıaqumica, 14(2): 253-264.

Choi, H. K. and Curhan, G. 2007. Coffee, tea, and caffeine consumption and serum uric acid level: the third national health and nutrition examination survey. Arthritis \& Rheumatism (Arthritis care \& Research), 57(5): 818-820.

Divya, S., Singh, R. and Bhatt, F. 2014. Development, quality evaluation and shelf life studies of Whey guava beverage. al. (2016), where they prepared a low-calorie herbal whey beverage using Stevia. Poornima and Puranik (2019) prepared ready to use health beverage by complete replacement of cane sugar with Stevia as a low-calorie natural sweetener. In contrast, complete replacement of sucrose with Stevia in health beverage was comparable with results obtained by Choi and Curhan (2007), who developed low-calorie soybean milk by adding $0.3 \mathrm{~g}$ stevia Leaf powder.

\section{Conclusion}

From the ongoing study, it can be concluded that a therapeutic Whey beverage could be prepared by blending papaya leaf extract at 20 per cent to paneer whey, followed by either sucrose (15 per cent) or Stevia (1.5 per cent). The study led to the profitable utilisation of both Papaya Leaf as well as Whey in beverage preparation which could be consumed by different sections of the population, which can be low-calorie beverage with health benefits of papaya leaf extract. However, further detailed studies are required to determine its composition, beneficial properties, and large-scale commercial application. Also, this therapeutic beverage may act as a source of beverage for people suffering from dengue due to the presence of papaya leaf extract.

International Journal of Current Engineering and Technology, 4(3): 2171- 2175.

Girisha, K. S. 2011. Development of kokum blended paneer Whey beverage. M.Sc. Thesis, submitted to Karnataka Veterinary, Animal and Fisheries Sciences University, Bidar, India, in partial fulfilment for the requirement for the degree of M.Sc.

Gupta, E., Purwar, S., Sundaram, S. and Rai, G. K. 2013. Nutritional and therapeutic values of stevia rebaudiana: a review. Journal of Medicinal Plants Research, 7(46):3343-3351.

Hazali, N., Mohamed, A. Muhammad, I., Masri, M., Isa, K. A. Md., Nor, N. Md., Ayob, M. K. and Fadzlan, F. N. M., 2014. Effect of Acute Stevia Consumption on Blood Glucose Response in Healthy Malay Young Adults. Sains Malaysiana, 43(5): 649-654.

Poornima. S, and Puranik, D. B. 2019. Effect of Functional Ingredients on the Sensory Characteristics of Ready to Use 


\section{Singh et al.}

Coffee Beverage. International Journal of Innovative Science and Research Technology, 3(4): 318-322.

Prashanth, B. M., Jayaprakash, H. M., Soumyashree, T. C. and Madhusudhan, N. M. 2018. Development of fruit enriched Whey beverage. International Journal of Chemical Studies, 6(2): 2386-2392.

Punnagaiarasi, A., Elango, A. and Karthikeyan, N. 2017. Sensory analysis of Whey-based watermelon beverage. International Journal of Science, Environment, 6(5): $3192-3155$

Rajarajan, G., Irshad, A., Raghunath, B. V., Kumar, G. M. and Punnagaiarsai, A. 2016. Utilisation of cheese industry Whey for biofuel ethanol production. Springer, 59-64.

Ritu, P. and Maya, D. 2016. Formulation of fruit (gauva fruit juice) and Whey based beverages flavoured with different herbs using natural sweetener as Stevia. International Journal of Advanced Research, 4(10): 2183-2187.
Roshan, A., Verma, N. K. and Gupta, A., 2014. A brief study on Carica Papaya- a review. International Journal of Current Trends in Pharmaceutical Research, 2(4):541550.

Shankarlingayya, S. 2014. Development of guduchipomogranate Whey beverage. M.Sc. Thesis submitted to faculty of Dairy Technology, Karnataka Veterinary, Animal and Fisheries Sciences University, Bidar, Karnataka, India, in the partial fulfilment for the requirement of degree of M.Sc.

Savita, S. M., Sheela, K., Sunanda, S., Shankar, A. G. and Ramakrishna, P., 2004. Stevia rebaudiana- A Functional Component for Food Industry. Journal of Human Ecology, 15(4):261-264.

Zar, J. H., 2003. Bio statistical analysis. J. H. Pub. Pearson Edu. Pvt. Ltd., New Delhi. 